\title{
Tomasz Gardziński
}

\section{Przedsiębiorczość społeczna w pandemicznym ładzie gospodarki rynkowej}

Streszczenie: Podejmowanym przez autora problemem badawczym jest obecny dryf ładu gospodarczego zwielokrotniony efektem mnożnikowym COVID-19 od zasad społecznej gospodarki rynkowej. Celem artykułu jest weryfikacja hipotezy, iż słabość polskiego ładu gospodarczego zainfekowanego koronawirusem może wspomóc przedsiębiorstwo społeczne jako amortyzator wykluczenia i alternatywa dla dotychczasowego paradygmatu rynkowego. Podjęcie tego tematu badawczego jest kontynuacją badań autora $\mathrm{w}$ zakresie komplementarności ordoliberalnego ładu gospodarczego społecznej gospodarki rynkowej z koncepcją przedsiębiorstwa społecznego. W jego przekonaniu, ta „mieszanka koncepcji” może stać się swoistą gospodarczą szczepionką dla rynku pod warunkiem konsekwentnego i kompleksowego stosowania w długim okresie. Badanie dotyczy stanu ładu gospodarczego po ponad roku pandemii w Polsce, na podstawie ordoliberalnych zasad i ich poszczególnych wyznaczników z wybranymi wskaźnikami gospodarczymi. Kluczowym wnioskiem opracowania jest to, że przedsiębiorstwo społeczne niwelując dysproporcje wspiera ład i tym samym może minimalizować negatywne skutki pandemii.

Słowa kluczowe: COVID 19, przedsiębiorstwo społeczne, ład gospodarczy, społeczna gospodarka rynkowa, ordoliberalizm

\section{A social enterprise in a pandemic economic order}

Summary: The research problem undertaken by the author is the current drift of the economic order multiplied by the multiplier effect of COVID-19 from the principles of the social market economy. The aim of the article is to verify the hypothesis that the weakness of the Polish economic order infected by the coronavirus may support a social enterprise as a shock absorber of exclusion and an alternative to the current market paradigm. Taking up this research topic is a continuation of the author's research on the complementarity of the ordoliberal economic order of the social market economy with the concept of the social enterprise. In his opinion, this "mixture of concepts" can constitute a specific economic vaccine for the market, 
provided that it is consistently and comprehensively used in the long term. The study concerns condition of the economic order after almost a year of the pandemic in Poland on the basis of ordoliberal rules and their individual determinants with selected economic indicators. The key conclusion of the study is that the social enterprise by reducing disproportions supports order and thus can minimize the negative effects of the pandemic.

Keywords: COVID 19, social enterprise, economic order, social market economy, ordoliberalism

JEL: L31, H12, I18

Po dwóch wojnach światowych, które dotknęły niemal cały glob, nikt się nie spodziewal, że ludziom może coś jeszcze zagrozić o zasięgu globalnym poza właśnie wojną światową. Okazało się, że dotychczasowy porządek społeczno-gospodarczy w skali światowej zaburzył wirus COVID-19, zabierając całej ludzkiej populacji poczucie „normalności”.

Autor artykułu podejmuje się zbadania głównych wskaźników makroekonomicznych w czasie epidemii i ich wpływu na przedsiębiorczość w Polsce, wykorzystując metodę badawczą jaką jest analiza komparatystyczna i statystyczna. Wyjątkowy stan zagrożenia zdrowia publicznego i gospodarki zmusza państwo do interwencjonizmu w zakresie tworzenia nowych reguł oraz reakcji w proces gospodarowania, m.in. w postaci obostrzeń epidemiologicznych. Jak wynika z przeglądu literatury, G.M. Malinowski stwierdza, że różne rządy na różne sposoby uciekają się do uwzględniania zasady ostrożności w uprawianej polityce społeczno-gospodarczej, co ułatwia podejmowanie decyzji, choćby na zasadzie, iż: lepiej jest się pomylić będąc zbyt ostrożnym, niż pomylić się będąc niedostatecznie ostrożnym (2020, s.6 i 7). Podejmowanie drastycznych działań w pandemicznych warunkach prewencyjnych sprawia, iż ład ekonomiczny kreowany przez państwo na kształt społecznej gospodarki rynkowej, słabnie. Ograniczana pobudkami medycznymi aktywność gospodarcza obywateli zwiększa bezrobocie i generuje dodatkowe koszty. Jak zauważa G.W. Kołodko, część z nich jest niezbędna ze względów socjalnych oraz dla ratowania i wspierania biznesu, część jest wyłudzana oraz źle adresowana i marnotrawiona (2020, s.5). Realizowanie założeń społecznej gospodarki rynkowej w dobie koronawirusa jest o wiele trudniejsze, gdyż sytuacja priorytetu zdrowia publicznego generuje kolejne decyzje interwencjonistyczne ze strony państwa. Decyzje takie, jak relacjonuje H.J. Wünsche, były dopuszczalne przez L. Erharda - autora wdrożenia tej koncepcji po wojnie w RFN, który uznawał politykę J.M. Keyenesa za przydatną w sytuacji, gdy trzeba uporać się z głębokim kryzysem gospodarczym (Mączyńska, Pysz, 2010, s.124). Gdy w kryzysie zdrowia publicznego cierpią pacjenci, cierpi również gospodarka, którą państwo podłącza do respiratora, aby jej płuca nadal mogły oddychać. Podmioty gospodarcze i społeczeństwo, kiedy państwo jest przeciążone problemami generowanymi przez pandemię, mogą sięgnąć również po pomoc przedsiębiorców społecznych. 


\section{Ład i przedsiębiorczość społeczna}

Pojmowanie rynku w kategorii ładu gospodarczego, który kształtuje państwo, autor przyjmuje zgodnie $\mathrm{z}$ oficjalnym ustrojem gospodarczym jaki jest zapisany w artykule 20 polskiej konstytucji, a mianowicie: Spoteczna gospodarka rynkowa oparta na wolności dziatalności gospodarczej, wtasności prywatnej oraz solidarności, dialogu i wspótpracy partnerów spotecznych stanowi podstawę ustroju gospodarczego Rzeczpospolitej Polskiej (Konstytucja Rzeczpospolitej Polskiej, 1997). Ponieważ w Polsce nadal nie ma definicji prawnej przedsiębiorstwa społecznego, poza jej projektem, autor odwołuje się do rozporządzenia Parlamentu Europejskiego i Rady w sprawie Programu Unii Europejskiej na rzecz przemian i innowacji społecznych, gdzie wytycza się miejsce i większą rolę dla przedsiębiorstw społecznych we współczesnym procesie rozwoju uznając, że: Gospodarka spotecznal i przedsiębiorczość spoteczna stanowiq integralna część pluralistycznej spotecznej gospodarki rynkowej Europy i odgrywają ważną rolę w zapewnianiu większej spójności spotecznej w Europie (Rozporządzenie Parlamentu Europejskiego i Rady, 2013, s. 241).

Ład gospodarczy, wg W. Euckena, to ogół form, w ramach których zachodzi kierowanie codziennym procesem gospodarowania (1989, s. 51). Ład gospodarczy to zatem stabilne formy i warunki ramowe przebiegu procesu gospodarowania, określające obowiązujące reguły gry gospodarczej, w ramach których państwo, przedsiębiorstwa, gospodarstwa domowe i jednostki ludzkie, podejmują decyzje i realizują działania gospodarcze (Pysz 2008, s.37). Materialnym zadaniem ładu gospodarczego jest przełamanie rzadkości dóbr i zasobów na ich optymalną alokację zapewniającą dobrobyt w społeczeństwie, przy zachowaniu wartości konstytutywnej rynku i państwa, tj. wolności oraz idącej za nią w poczuciu odpowiedzialności wartości sprawiedliwości społecznej urzeczywistnianej przez wyrównywanie materialnych szans konkurowania (Gardziński 2020, s.97-98). Ład gospodarczy jest zatem nierozerwalnie związany ze społeczną gospodarką rynkową. Jej pojęcie, jako syntezy wolności na rynku z realizacją celów zabezpieczenia socjalnego, wprowadził Alfred Müller-Armack (H.F. Wünche, 2000, s.207). Natomiast jej autor - Ludwig Erhard, wprowadził ją w życie w powojennych Niemczech jako syntezę zasady wolności na rynku z równością społeczną i moralną odpowiedzialnością każdej jednostki ludzkiej w stosunku do społeczeństwa jako całości (L. Erhard, s.515), co zapewniło „dobrobyt dla wszystkich” i dobrobyt poprzez konkurencję - postulaty ściśle ze sobą sprzężone, nierozłączne: pierwszy określa cel, drugi zaś drogę prowadzącą do tego celu (Erhard, s.20). Fundamentem społecznej gospodarki rynkowej, na którym opiera się ład, jest ordoliberalizm. Jak zauważa M. Moszyński, koncepcja SGR ${ }^{2}$ jest ideologicznym rozwinięciem i praktyczną aplikacją ordoliberalizmu, który stanowi niemiecki wkład do rozwoju myśli ekonomicznej i społecznej (2020, s.9). Ordoliberalizm natomiast jest doktryną ekonomiczną z uporządkowanym społecznym liberalizmem. W dużym uproszczeniu możemy stwierdzić, że ordoliberalizm opowiada się za silnym państwem, jako podmiotem gwarantującym sprawne funkcjonowa-

\footnotetext{
W literaturze spotyka się utożsamienie gospodarki społecznej ze społeczną gospodarkę rynkową, a jest to niewłaściwe rozumienie pojęć. Społeczna gospodarka rynkowa nawiązuje do niemieckiego ordoliberalizmu - więcej na ten temat w artykule Eweliny Florczak „Przedsiębiorstwo spoteczne”.

2 SGR - Społeczna Gospodarka Rynkowa.
} 
nie wolnego rynku w ramach stanowionego ładu gospodarczego, gdzie szczególna uwaga w tym zakresie poświęcona jest stworzeniu w danym państwie systemu prawnego, dzięki któremu państwo może posiadać odpowiednie instrumenty przeciwdziałania procesowi koncentracji władzy, zarówno tej ekonomicznej jak i politycznej (Dahl, 2020, s.394). Czołowym przedstawicielem ordoliberałów ze „szkoły fryburskiej” był W. Eucken, który uporządkował liberalizm, opracowując zasady konstytuujące i regulujące adoptowane do koncepcji społecznej gospodarki rynkowej.

Polityka ustroju opartego na konkurencji opiera się na zasadach konstytuujących, do których należą (Mączyńska, Pysz, 2003, s.73-103): zasada generalna gdzie ceny pełnią funkcję wskaźnika rzadkości dóbr i zasobów, drugą zasadą jest stabilna polityka walutowa, trzecią rynek otwarty na „wejścia” i „wyjścia” podmiotów gospodarczych, czwartą zasadą jest własność prywatna środków produkcji, piątą swoboda zawierania umów, szóstą odpowiedzialność materialna za wyniki prowadzonej działalności, kolejną jest stabilność polityki gospodarczej i ostatnią spójność zasad rozumiana jako ich współzależność. Natomiast do zasad regulujących należą (Eucken, 2005, s.295-330): kontrola monopoli celem zapewnienia porządku konkurencji, czyli obecnie państwo musi być silniejsze niż przypływy kapitałowe monopolistów ponad granicami (np. prawo antytrustowe w USA), polityka dochodowa uwzględniająca redystrybucję dochodu gdy powstają rażące różnice pomiędzy podmiotami gospodarczymi, rachunek gospodarczy gdzie uwzględnia się efekty zewnętrzne przedsiębiorstw przerzucanych często na społeczeństwo oraz przeciwdziałanie anormalnym zachowaniom po stronie podaży. Jak zauważa i podkreśla P. Pysz, do zasad ładu społecznej gospodarki rynkowej w ujęciu L. Erharda należy zaliczyć: konkurencję rynkową, pełne zatrudnienie, stabilność cen, dywersyfikację substancji majątkowej w społeczeństwie (2008, s.103), na czym autor skupi swoją uwagę w niniejszym opracowaniu. Poprzez kompleksowe stosowanie zasad w długim okresie, ład społeczno-gospodarczy ma zapewniać dobrobyt dla wszystkich. Zasady powinny umożliwiać kształtowanie przez politykę gospodarczą takich form ładu gospodarczego, które skłonią podmioty gospodarcze za pośrednictwem alokacyjnej funkcji cen konkurencji doskonałej - do optymalnej alokacji dóbr i zasobów (Pysz, Jurczuk, 2021, s.28).

Ordoliberlany ład gospodarczy społecznej gospodarki rynkowej zakłada nierozerwalność polityki ekonomicznej i społecznej. Polityka społeczna według Euckena, nie może być dodatkiem do reszty polityki gospodarczej, gdyż wszystkie rodzaje tejże polityki mają ostatecznie wymiar społeczny (Moszyński, 2016, s. 36). Jak możemy zaobserwować, rządzący nie traktują polityki ekonomicznej ze społeczną jako całości i nie pamiętają lub nie są w stanie zawsze pomóc wykluczonym. Aby uniknąć zatem dyskrecjonalnych działań rządzących, wynikających z wykluczenia słabszych jednostek z gry rynkowej, państwo powinno stwarzać również ramy prawne charakterystyczne dla ładu kooperacyjnego panującego w przedsiębiorczości społecznej, które umożliwią słabszemu obywatelowi podjęcie działań w ramach samopomocy i wzięcie odpowiedzialności za swój los, zanim zwróci się o pomoc do państwa (Gardziński, Łabenda, 2020, s.12). $\mathrm{Z}$ jednej strony zatem państwo powinno stwarzać możliwości rozwoju przedsiębiorczości społecznej jako możliwości samopomocy, a z drugiej powinno być gotowe na udzie- 


\section{Tablica 1 Kryteria przedsiębiorstwa społecznego wg sieci EMES}

\begin{tabular}{ll}
\multicolumn{2}{c}{ PRZEDSIĘBIORSTWO SPOŁECZNE } \\
kryteria ekonomiczne & kryteria społeczne \\
\hline stała działalność produkcji dóbr i/lub sprzedaży usług & społecznie użyteczny cel dla rozwoju lokalnego \\
wyraźny stopień autonomii & oddolna inicjatywa lokalna \\
ponoszenie znaczącego ryzyka ekonomicznego & demokratyczne zarządzanie \\
istnienie minimalnego personelu płatnego & partycypacyjny charakter \\
& ograniczona dystrybucja zysków
\end{tabular}

Źródło: opracowano na podstawie Defourny, 2008, s. 80-81.

lenie pomocy społecznej. Jak podkreśla M. Dahl, w myśl zasady subsydiarności, dopiero w sytuacji gdy wyczerpane zostaną wszystkie możliwości samopomocy, obywatele powinni otrzymać pomoc ze strony państwa (2015, s.57). Komplementarność zatem obu koncepcji wynika nie tylko z prospołecznego azymutu, ale również z tego, że tam gdzie kończy się jedna zaczyna się druga, w wyniku czego się zazębiają. To sprawia, że w ordoliberalnym ładzie społecznej gospodarki rynkowej pojawia w naturalny sposób miejsce na przedsiębiorstwo społeczne oparte na kooperacji, które w ramach samopomocy opartej na zaufaniu i poczuciu wspólnej sprawy, wyręcza państwo (Brdulak, Florczak, Gardziński, 2020, s.40).

Definiowanie przedsiębiorstwa społecznego $(\mathrm{PS})^{3} \mathrm{w}$ opinii autora nie powinno skupiać się na kategorii formalno-prawnej, lecz na faktycznej jego działalności i społecznego zarządzania zyskiem. W związku z tym uwzględnia kryterium koncentrowania zysku na celach społecznych i zarazem dowolną formę instytucjonalno-prawną, przyjmując ostatecznie za J. Brdulakiem i E. Florczak, że przedsiębiorstwo społeczne to przedsiębiorstwo realizujące cele społeczne w ramach właściwej mu części zysku - znaczącej ze względu na realizowany cel (Brdulak, Florczak, Gardziński, 2020, s.82). Natomiast przedsiębiorczość społeczna to nieco szersze pojęcie.

W literaturze jest rozumiana jako mechanizm tworzenia przedsiębiorstw społecznych i jako bezpośrednia metoda produkcji dóbr i usług przez stowarzyszenia i fundacje oraz inne formy gospodarki społecznej (Leś, 2008, s.40). Jest inaczej rozumiana w Europie, jako część gospodarki społecznej związanej z ruchami społecznymi, spółdzielczymi, organizacjami trzeciego sektora i polityką publiczną, gdzie inicjator to grupa społeczna, a w USA jako innowacyjne rozwiązanie na palące problemy społeczne, którego inicjatorem są charyzmatyczne i przedsiębiorcze jednostki. Przywołując tu według J. Schumpetera koncepcje przedsiębiorcy jako innowatora, J. Defourny zaznacza, że można obecnie mówić o nowej przedsiębiorczości społecznej, której rozwiązania mogą dotyczyć (2009, s.4-7): wprowadzenia na rynek nowego produktu lub nowej jakości produktu, wprowadzenia alternatywnych metod organizacji i/lub produkcji, tworzenie nowych przestrzeni rynkowych, zdobycia nowego źródła surowców lub odnowienia danej branży organizacji, pozyskania nowych relacji z rynkiem, również polegające na nowych rozwiązaniach systemowych i układzie partnerstw z przedstawicielami różnych środowisk. Według D. Jarré, przedsię-

3 PS - przedsiębiorstwo społeczne 


\section{Rysunek 1 Państwo, rynek, organizacje niedochodowe w kontekście}

\section{przedsiębiorstwa społecznego}

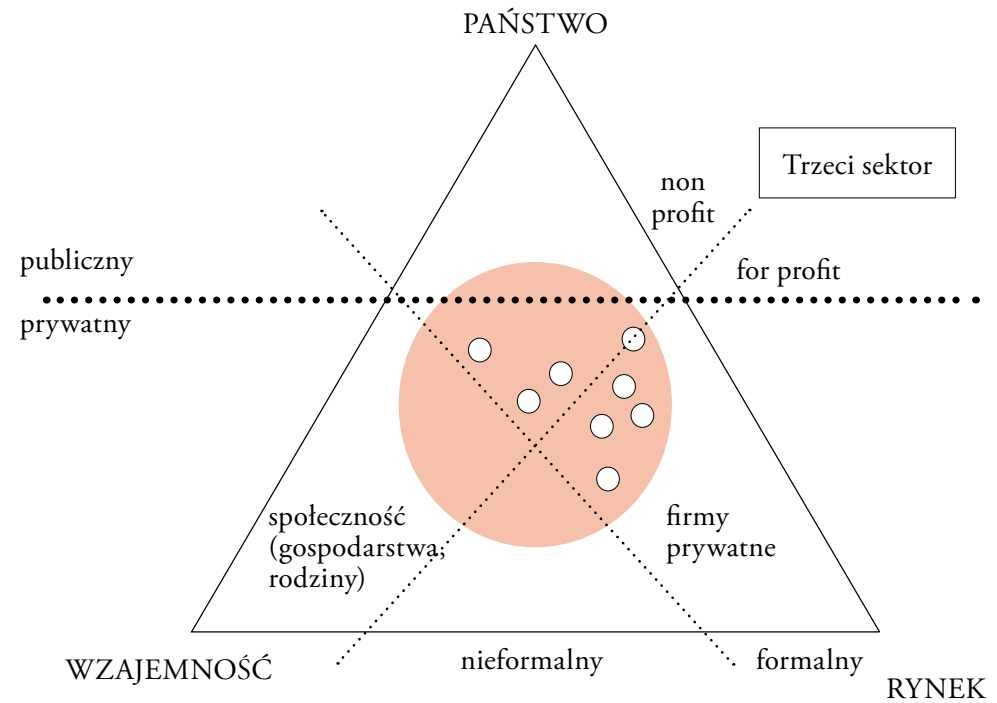

Źródło: opracowanie własne na podstawie Defourny, Nyssens, 2007.

biorczość społeczna to jeden z instrumentów umożliwiających modelowi welfare osiągania jego celów, gdyż w niektórych krajach jest istotnym dostawcą usług zdrowotnych, opiekuńczych, w zakresie ochrony środowiska, dostępnego budownictwa, efektywnego wykorzystania źródeł energii, edukacji i niekiedy zapewnia finansowanie tych usług (Leś, 2007, s.7). Ignorowane dotąd przez rynek lub państwo potrzeby mieszkańców zostają zaspokojone przez przedsiębiorczość społeczną, co jest w dobie pandemii znakomitą wartością społeczno-ekonomiczną.

W ujęciu europejskim, kryteria przedsiębiorstwa społecznego na zlecenie Komisji Europejskiej przedstawia Europejska Sieć Badawcza EMES ${ }^{4}$ Network (The Emergence of Social Enterprise in Europe), definiując orientacyjne ekonomiczne i społeczne jego wyznaczniki (tablica 1). Podmioty gospodarki społecznej zapewniają odpłatne zatrudnienie ponad 14,5 mln osób, czyli ok. 6,5 proc. osób czynnych zawodowo w krajach w Unii Europejskiej i wytwarzają ok. 10 proc. PKB (Brdulak, Florczak, Gardziński, 2019, s.80-81).

Europejska koncepcja przedsiębiorstwa społecznego, jak widać na rysunku 1, opiera się na azymutach państwa, rynku i organizacji niedochodowych, będących synonimem społeczeństwa obywatelskiego utożsamianego z wzajemnością. Tradycja europejska ma tendencje do łączenia trzeciego sektora utożsamianego z sektorem niedochodowym (non-profit) i organizacjami pozarządowymi z gospodarką społeczną. Ponieważ autor niniejszego opracowania korzysta w dalszej jego części z danych statystycznych GUS w zakresie działalności podmiotów przedsiębiorczości społecznej w czasie epidemii COVID-19, uza-

EMES - Europejska Sieć Badawcza powstała w 1996 r. gdy zrealizowano projekt badawczy „Powstanie przedsiębiorstw społecznych w Europie”. W roku 2002 zarejestrowana została jako organizacja pozarządowa i zrzesza uczelnie i centra badawcze. 


\section{Rysunek 2 Inflacja w miesiącach w latach 2019-2021}

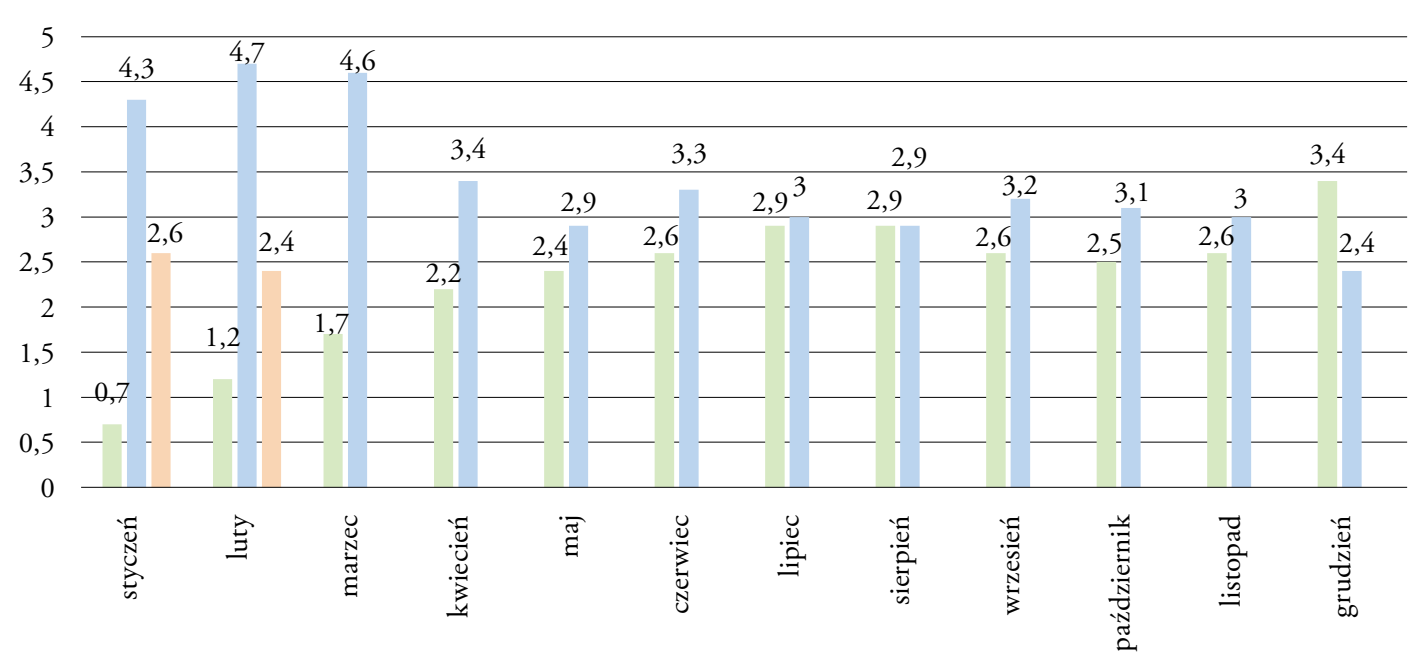

rok $2019 \square \operatorname{rok} 2020 \quad \operatorname{rok} 2021$

Źródło: opracowanie własne na podstawie GUS, https://stat.gov.pl/obszary-tematyczne/ceny-handel/wskazniki-cen/ wskazniki-cen-towarow-i-uslug-konsumpcyjnych-w-lutym-2021-roku,2,112.html (dostęp 07.04.2021).

sadnionym jest przywołanie definicji gospodarki społecznej dla celów rachunków narodowych, przez którą należy rozumieć: ogót prywatnych, zorganizowanych formalnie przedsiębiorstw dysponujacych autonomia podejmowania decyzji i cechujących się dobrowolnym cztonkostwem, które zostaty stworzone w celu zaspokajania potrzeb swoich cztonków za pośrednictwem rynku, poprzez wytwarzanie towarów i świadczenie ustug, zapewnianie ubezpieczenia i finansowania, w których ewentualny podziat zysków lub nadwyżek pomiędzy cztonków ani podejmowanie decyzji, nie wiąża się bezpośrednio z kapitatem lub wktadem wniesionym przez każdego z cztonków, z których każdy dysponuje jednym gtosem. Gospodarka spoteczna obejmuje również prywatne, zorganizowane formalnie organizacje dysponujące autonomia podejmowania decyzji i cechujących się dobrowolnym cztonkostwem, które świadcza ustugi nierynkowe na rzecz gospodarstw domowych $i$ których nadwyżki, o ile takowe wystapia, nie moga być przywtaszczone przez podmioty gospodarcze tworzace, kontrolujące lub finansujace owe organizacje. (Gospodarka społeczna w Unii Europejskiej, 2006, s.6)

\section{Wskaźniki ekonomiczne zainfekowanej gospodarki ${ }^{5}$ a wpływ przedsiębiorczości społecznej}

Aby zbadać wpływ przedsiębiorczości społecznej na gospodarkę, należy sobie odpowiedzieć na pytanie, na jakich obszarach zwykle powstają przedsiębiorstwa społeczne w warunkach bez epidemii, co określa (Duczkowska-Małysz, 2012, s. 503):

\footnotetext{
Ze względu na ograniczenia ilościowe opracowania, autor w miarę możliwości zestawi powyższe uwarunkowania z najważniejszymi zasadami społecznej gospodarki rynkowej (konkurencja rynkowa, pełne zatrudnienie, stabilność cen, dywersyfikacja substancji majątkowej w społeczeństwie) zobrazowanymi wskaźnikami gospodarczymi bez szczegółowych aktualnych wyznaczników opracowanych przez polskich uczonych zajmujących się stanowionym i spontanicznym ładem gospodarczym w procesie transformacji (Grabska, Moszyński, Pysz 2014), co będzie okazją do kolejnego szerszego opracowania.
} 


\section{Rysunek 3 Stopa bezrobocia w miesiącach w 2020 i 2021 roku}

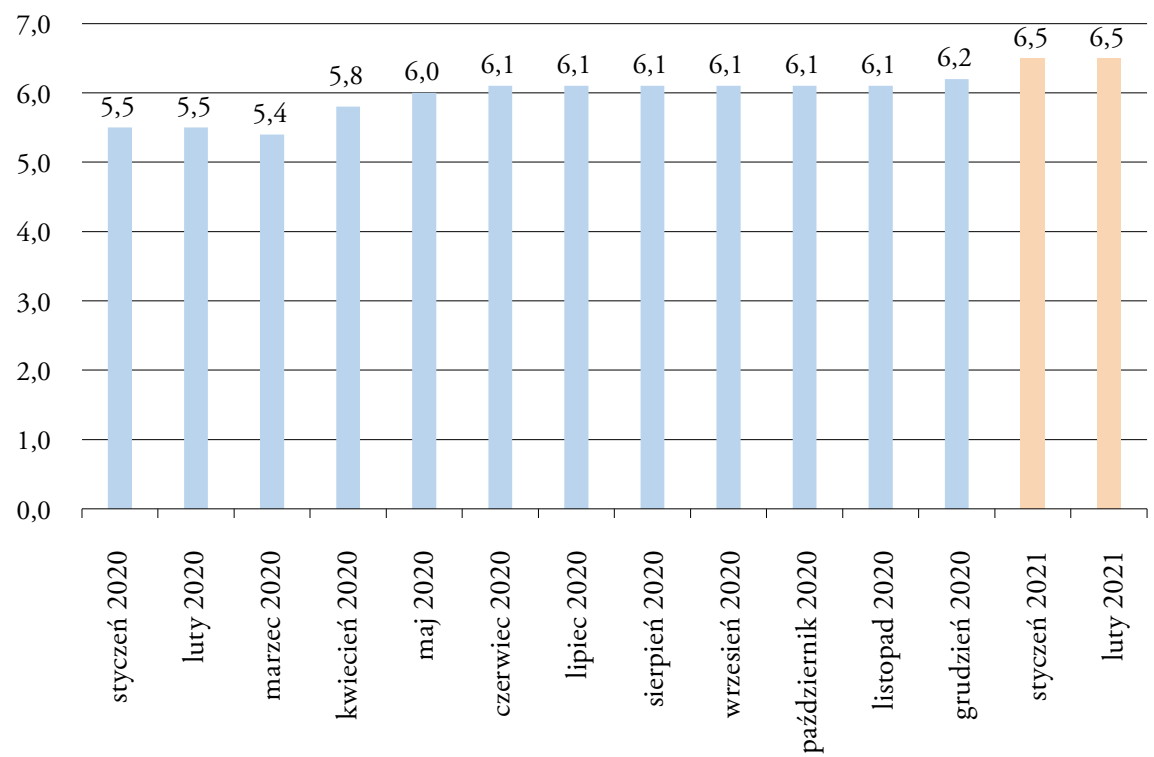

Źródło: opracowanie własne na podstawie GUS, https://stat.gov.pl/wskazniki-makroekonomiczne/ (dostęp 12.04.2021).

1. stopa bezrobocia jest znacznie wyższa niż przeciętna, a trwale bezrobotni nie mają szans na znalezienie pracy. Wskazuje to na skierowanie przedsiębiorstw społecznych do środowisk wykluczonych społecznie;

\section{Rysunek 4 Przeciętne zatrudnienie w sektorze przedsiębiorstwa w tys.}

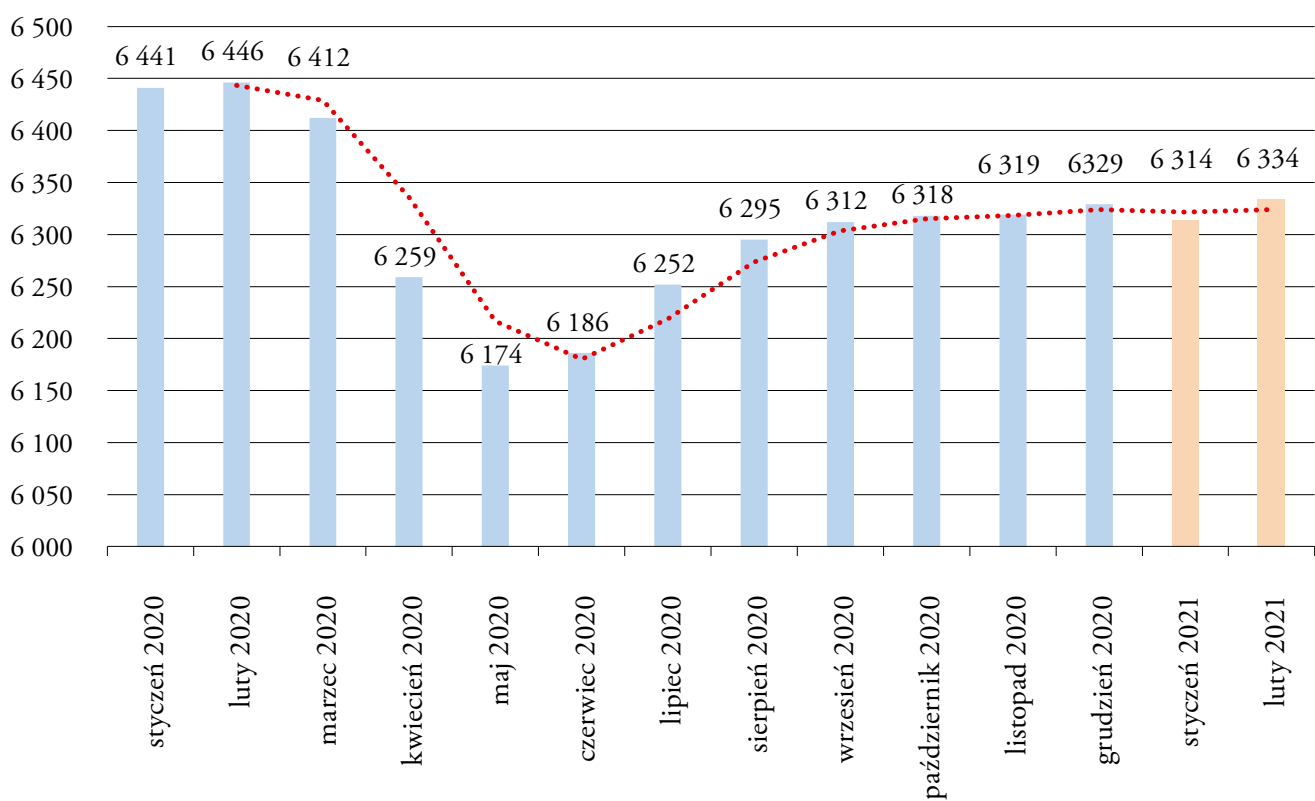




\section{Rysunek 5 PKB kwartalnie dla 2019 i 2020 roku}

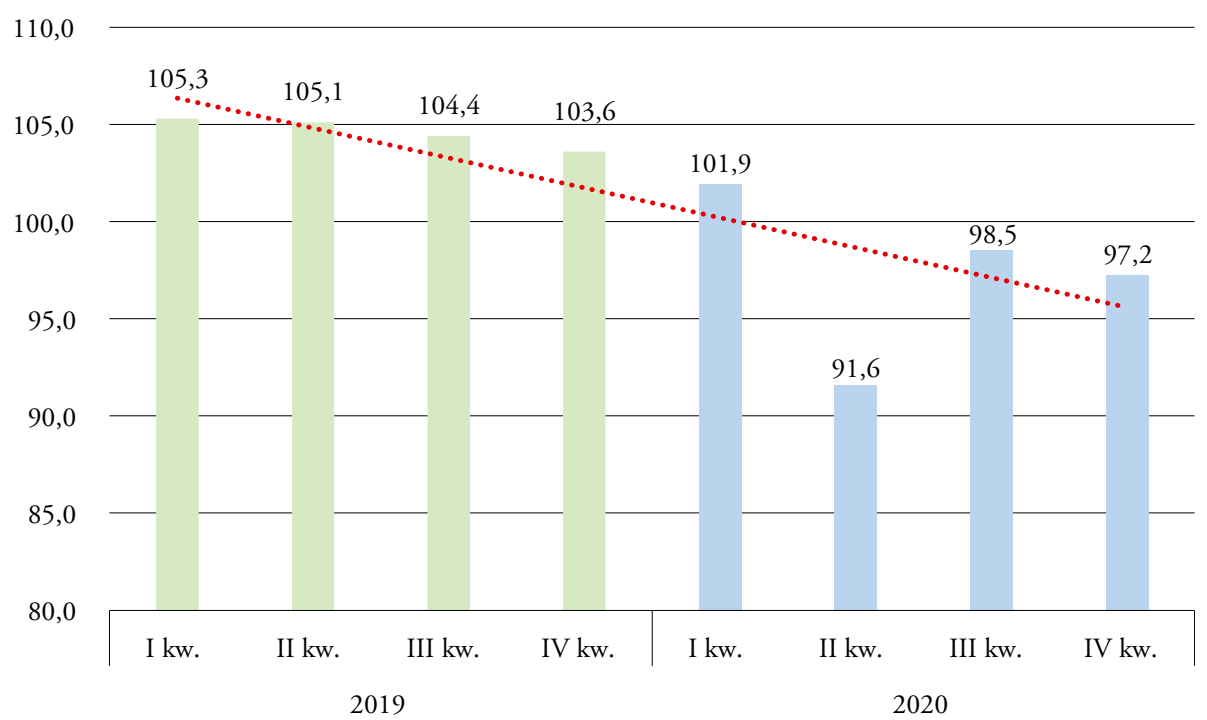

Źródło: opracowanie własne na podstawie GUS, https://stat.gov.pl/obszary-tematyczne/rachunki-narodowe/kwartalne-rachunki-narodowe/wstepny-szacunek-produktu-krajowego-brutto-w-czwartym-kwartale-2020-roku,3,74.html (dostęp 17.04.2021).

2. wadliwe struktury gospodarki nie są $\mathrm{w}$ stanie o własnych siłach modernizować się i wytwarzać innowacyjnych produktów; mankamenty zaplecza technicznoinfrastrukturalnego w gospodarce lokalnej uzupełnia się kapitałem społecznym, lokalną solidarnością i współdziałaniem;

3. wadliwe struktury demograficzne wskazują na trudności na rynku pracy, które będą wymagać specjalnych rozwiązań, które również wskazują na określony typ popytu usługowego zgłaszanego ze strony społeczności lokalnej;

4. rejestruje się degradację naturalnych i kulturowych funkcji zasobów regionu;

5. słabo rozwinięta infrastruktura techniczna i społeczna blokuje procesy rozwoju gospodarczego.

Zestawiając powyższe uwarunkowania z najważniejszymi zasadami SGR, zaczniemy od reguły ładu konkurencyjnego, jakim jest stabilna wartość pieniądza. Jak widać na rysunku 2, stopa inflacji utrzymywała się na wyższym poziomie powyżej 4 proc. od stycznia do marca 2020 roku, po czym trend od kwietnia do niemal listopada 2020 oscylował wokół 3 proc., by z końcem roku i początkiem 2021 roku zająć średni poziom 2,5 proc. Wbrew różnym opiniom (np. NBP) o czekającej nas deflacji, czy też teorii o nadciągającej galopującej inflacji, mamy do czynienia z umiarkowaną inflacją pomimo niepewności na rynku energii, ale i wpływu ceny paliwa, a także wzrostu podatków, w tym niektórych dóbr koszyka konsumpcyjnego, pomimo że na tle innych krajów mieliśmy wyższą inflację w kilku miesiącach ubiegłego roku. Stabilność wartości pieniądza jest jedną z najważniejszych ordoliberalnych zasad, ponieważ wysoka inflacja była uważana za równie groźną dla społeczeństwa co wojna. Ponadto, wysoka inflacja uderza najpierw w najbiedniejsze war- 
stwy społeczne, co zawsze generowało napięcia w społeczeństwie, dlatego powinna być traktowana do utrzymania w kontroli jako priorytet.

Wykluczenie społeczne często zaczyna się wraz z bezrobociem, które dla Polski było prognozowane przez Komisję Europejską na poziomie 7,5 proc. w 2020 roku i 5,3 proc. w 2021 roku.

Bezrobocie w Polsce zwiększyło się o 1 proc. na przestrzeni roku (rysunek 3) pomimo wyższej prognozy Komisji Europejskiej i prognoz ekonomistów, którzy szacowali nawet dwucyfrowe bezrobocie z końcem roku 2020. Oczywiście warto pamiętać, że bezrobocie do poziomu 5 proc. spadło w wyniku obniżenia wieku emerytalnego, co spowoduje większy koszt przyszłych pokoleń, natomiast jego wzrost należy uznać również za umiarkowany. Natomiast celem społecznej gospodarki rynkowej jest osiągnięcie pełnego zatrudnienia, więc nie jest do powód do osiadania na laurach. A jak widać na rysunku 4, przeciętne zatrudnienie wyraźnie spadło miesiąc po rozpoczęciu pandemii i najmniejsze było w maju - 6174, by w późniejszych miesiącach odrobić straty. Jak podaje GUS, w lutym 2021 r. przeciętne zatrudnienie w sektorze przedsiębiorstw było niższe o 1,7 proc. $\mathrm{r} / \mathrm{r}$ i wyniosło 6334,0 tys.

Ostatnim wská́nikiem obrazującym najlepiej stan gospodarki, ale oczywiście nie jest to najlepszy miernik substancji majątkowej w społeczeństwie, jest wzrost PKB.

Dynamika realna produktu krajowego brutto na rysunku 5, jest niewyrównana sezonowo (ceny średnioroczne roku poprzedniego) przy podstawie analogiczny okres roku

\section{Rysunek 6 Odsetek organizacji non-profit podejmujących dodatkowe działania na rzecz odbiorców w związku z epidemią COVID-19 w okresie od marca do sierpnia 2020 r. według rodzaju organizacji}

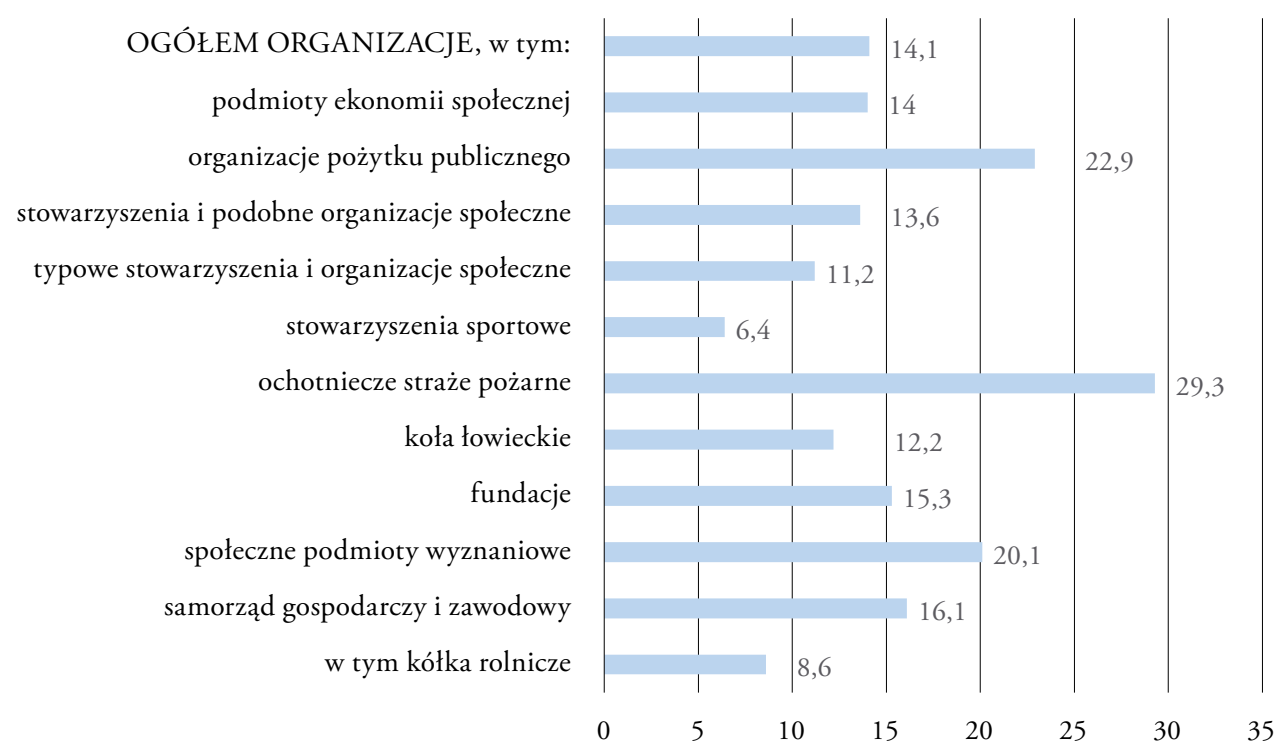

Źródło: opracowanie własne na podstawie GUS, https://stat.gov.pl/obszary-tematyczne/gospodarka-spoleczna-wolontariat/gospodarka-spoleczna-trzeci-sektor/organizacje-non-profit-w-czasie-epidemii-covid-19-marzec-sierpien-2020,20,1. html (dostęp 07.04.2021). 
poprzedniego $=100$. Największy spadek PKB miał miejsce $\mathrm{w}$ II kwartale $2020 \mathrm{roku}$, co nie dziwi ze względu na to, że pierwszy przypadek koronowirusa w Polsce miał miejsce 4 marca. W III kwartale PKB zaczął odrabiać straty po szoku, gdy pandemia zaczęła się dla gospodarki w postaci wprowadzenia obostrzeń. Produkt krajowy brutto (PKB) w IV kwartale 2020 r. zmniejszył się realnie o 2,8 proc. rok do roku, wobec wzrostu o 3,6 proc. w analogicznym kwartale 2019 (w cenach stałych średniorocznych roku poprzedniego). Jest to mniejszy spadek niż w Unii Europejskiej, gdzie PKB obniżył się w zeszłym roku o 7,4 proc.

Jak podaje GUS w raporcie Organizacje non-profit w czasie epidemii COVID-19 (marzec - sierpień 2020), w okresie od marca do sierpnia 2020 r. 14,1 proc. organizacji non-profit (rysunek 6) podjęło dodatkowe działania w związku z epidemią COVID-19.

Najczęściej były to usługi społeczne (63,3 proc.) lub wsparcie materialne (40,7 proc.). W tym okresie organizacje przekazały wsparcie rzeczowe i finansowe o łącznej wartości 383,3 mln zł (GUS, 2020, s.1). Od marca do sierpnia 2020 r. objęto łącznie pomocą blisko 2 mln prywatnych osób fizycznych, gdy dla porównania w tym okresie w całym kraju koronawirusem zaraziło się 67,4 tys. osób. Organizacje przedsiębiorczości społecznej najczęściej podejmowały dodatkowe działania na rzecz prywatnych osób fizycznych $(54,9$ proc.), następnie wskazywano całe społeczności (np. osiedle, sołectwo, gmina) - 31,0 proc. oraz placówki ochrony zdrowia (17,8 proc.) (GUS, 2020, s 2). Niestety, w powyższym raporcie organizacje non-profit przewidują, że ponad w $1 / 3$ ogółu tych organizacji dojdzie do pogorszenia sytuacji finansowej, a obniżenie poziomu zatrudnienia przewiduje 14,4 proc. ogółu organizacji non-profit, co jest oczywistą przesłanką do tego, że takie podmioty przedsiębiorczości społecznej powinny wspomagać państwo zanim zwrócą się do niego bezpośrednio beneficjenci tych organizacji. Tym sposobem komercyjne, wspierane przez państwo przedsiębiorstwo społeczne, będzie coraz ważniejszym czynnikiem uspołecznienia kapitału i poprawy jakości życia społeczno-gospodarczego. Nie tylko w czasie pandemii. Tym samym, skutki samopowielającej się akumulacji kapitału będą mogły stopniowo także ulegać uspołecznieniu (Brdulak, Florczak, Gardziński, 2019, s.8).

Reasumując, słabość polskiego ładu gospodarczego zainfekowanego koronawirusem może wspomóc przedsiębiorstwo społeczne jako amortyzator wykluczenia i alternatywa dla dotychczasowego paradygmatu rynkowego. Rzeczą drugorzędną jest zakres i skala.

\section{Podsumowanie}

XXI wiek, zarówno w ekonomii jak i w zarządzaniu, niesie zmiany w paradygmacie neoliberalnym, nastawionym głównie na maksymalizację zysku w działalności gospodarczej (Dahl, Florczak, 2021 s.9). Zmiana paradygmatu w ekonomii jest niezbędna zarówno na poziomie mikro i makro. Tak rozumiana przedsiębiorczość społeczna jest odbierana jako reakcja w opozycji do kapitalistycznej praktyki gospodarczej, która nie uwzględnia podmiotowości człowieka w procesie gospodarczym (Brdulak, Florczak, 2016, s.47) Nietrwałość paradygmatu dwubiegunowego, opartego na państwie i rynku zauważa również C. Borzaga i postuluje nowy paradygmat, który umiejscowi obywatelskie działania na rzecz dobra ogólnego obok działań państwa, rynku i rodziny (2007, s.81 i 92). 
Zmiana paradygmatu o kolejny biegun, tj. przedsiębiorstwa społecznego, powinna odbywać się najlepiej w ładzie społecznej gospodarki rynkowej, gdyż takie przedsiębiorstwo może działać również bez takiego ładu. Cele społecznej gospodarki rynkowej oparte na wolności, odpowiedzialności, zasadzie sprawiedliwości społecznej, godności ludzkiej, zasadzie konkurencji i silnego państwa prawa, w znacznym stopniu odnoszą się do funkcji przedsiębiorstw społecznych działających również poza klasycznym ładem społecznej gospodarki rynkowej (Florczak, Gardziński, 2019, s.140). Jednak w kontekście COVID-19 optymalne jest, aby przedsiębiorstwa społeczne funkcjonowały w ramach społecznej gospodarki rynkowej, realizując zbieżne cele takie jak aspekt społeczny; konkurencyjność (w przypadku przedsiębiorstw społecznych, które aby utrzymać się na rynku muszą maksymalizować zysk niezbędny do przetrwania przedsiębiorstwa); partnerstwo i współdecydowanie rozumiane podobnie w koncepcji PS i SGR; problem nierówności społecznych; subsydiarność i pomocniczość jako oś spajająca obie koncepcje. W takiej konstelacji i ładzie, choćby taki wskaźnik jak wzrost gospodarczy to nie tylko życzeniowe przełamanie rzadkości dóbr i zasobów przez ich optymalną alokację, ale również w miarę równomierne rozłożenie substancji majątkowej w społeczeństwie. Potwierdzają to słowa G.W. Kołodko, że wzrost gospodarczy jest bardziej trwały w krajach o względnie niskim stopniu nierówności dochodowych i co więcej, relacje dochodowe ważyły tam na dynamice więcej niż liberalizacja handlu i jakość instytucji politycznych (2013, s. 378).

Reasumując, 14,1 proc. pomiotów przedsiębiorczości społecznej w czasie pandemii Covid-19 w Polsce (w okresie od marca do sierpnia 2020) wsparło 2 miliony osób w ramach usług społecznych (63,3 proc.) lub wsparcia materialnego (40,7 proc.) w łącznej kwocie 383,3 mln zł. Powyższe dane, zdaniem autora, są wystarczające na potwierdzenie postawionej na wstępie hipotezy, że osłabiony przez koronawirusa ład społecznej gospodarki rynkowej może zostać wsparty przez podmioty przedsiębiorczości społecznej. Autor zdaje sobie sprawę ze zmiany pozycji państw narodowych w stosunku do wielkiego kapitału. Jednak obecnie oczekuje się odpowiedzialnego rozwoju i ładu zarówno od państwa jak i od kapitału prospołeczności i odpowiedzialności, bez których ludzkość nie przetrwa egzystencjalnie. Na te wyzwania odpowiedzią może być przedsiębiorczość społeczna w nowym ładzie społecznej gospodarki rynkowej.

\section{Bibliografia:}

1. Borzaga C. (2007), Nowe trendy w partycypacji obywatelskiej: rosnąca rola zachowań spotecznie odpowiedzialnych w konsumpcji, oszczędzaniu i produkcji, [w:] Przedsiębiorstwo spoteczne w rozwoju lokalnym, E, Leś, M. Ołdak (red.), Tom 2 Zeszytów gospodarki społecznej, Collegium Civitas Press, Warszawa, s. 79-100.

2. Brdulak J., Florczak E., Gardziński T. (2020), Przedsiębiorstwo spoteczne elementem wspótczesnego tadu gospodarki kapitalistycznej, Kwartalnik Nauk O Przedsiębiorstwie $55 \mathrm{Nr}$ 2, s. 29-42. 
3. Brdulak J., Florczak E., Gardziński T. (2020), Przedsiębiorstwo spoteczne szansq zmniejszania kosztów napięć we wspótczesnym kapitalizmie, [w:] Prospoteczność w życiu spoteczno-gospodarczym w XXI wieku, M. Dahl, E. Florczak (red.), Oficyna Wydawnicza Uczelni Łazarskiego, Warszawa, s. 75-96.

4. Brdulak J., Florczak E., Gardziński T. (2017), Przedsiębiorstwo spoteczne w kulturze odpowiedzialnego rozwoju, [w:] Partycki S., Sobiecki R. (red.), Wartości i nowoczesność w strategii odpowiedzialnego rozwoju, KUL, Lublin, s. 101-113.

5. Brdulak J., Florczak E., Gardziński T. (2019), The Socialization of Capitalism through Social Enterprises, "International Journal of Small and Medium Enterprises and Business Sustainability", Vol. 2(4), s. 66-87.

6. Brdulak J., Florczak E., Gardziński T. (2019), Uspotecznienie kapitalizmu w Europie ŚrodkowoWschodniej, „Myśl Ekonomiczna i Polityczna” 2019 nr 1(64), s. 74-95.

7. Brdulak J, Florczak E. (2016), Uwarunkowania dziatalności przedsiębiorstw spotecznych w Polsce, Oficyna Wydawnicza Uczelni Łazarskiego, Warszawa.

8. Dahl M. (2015), Niemiecki Model Spotecznej Gospodarki Rynkowej jako wzór dla polskich przemian systemowych po 1989 roku, Dom Wydawniczy Elipsa, Warszawa.

9. Dahl M. (2020), Znaczenie dorobku prawnego Franza Böhma w interdyscyplinarnych badaniach nad ordoliberalizmem, International Journal of Legal Studies, Międzynarodowy Instytut Innowacji NaukaEdukacja-Rozwój w Warszawie, Polska, s. 393-403.

10. Dahl M., Florczak E. (red.) (2021), Prospoteczność w życiu spoteczno-gospodarczym w XXI wieku, Oficyna Wydawnicza Uczelni Łazarskiego, Warszawa.

11. Defourny J. (2009), Concepts and Realities of Social Enterprise: A European Perspective, Paper presented at the Second Research Colloquium on Social Entrepreneurship, Duke University, NC, June, 23-26, p. $4-7$.

12. Defourny J. (2008), Od trzeciego sektora do przedsiębiorstwa spotecznego, w: Antologia kluczowych tekstów. Przedsiębiorstwo spoteczne, J.J. Wygnański (red.), FISE, Warszawa, s. 65-90.

13. Duczkowska-Małysz K. (2012), Ekonomia spoteczna a rozwój przedsiębiorczości, w: Między ekonomia. a historia, R. Dziemianowicz, A. Kargol-Wasiluk, J. Wilkin, M. Zalesko (red.), Wydawnictwo Uniwersytetu w Białymstoku, Białystok.

14. Erhard L. (1988), Wirtschaft und Bildung, w: Erhard, L., Gedanken aus fünfJarhrzehnten, red. K. Hohmann, Econ Verlag, Düsseldorf-Wien-New York.

15. Erhard L. (2011), Dobrobyt dla wszystkich, Polskie Towarzystwo Ekonomiczne, Warszawa.

16. Eucken W. (1989), Die Grundlagen der Nationalökonomie, 9. Aufl. Springer-Verlag, Berlin s. 51.

17. Eucken W. (2005), Podstawy polityki gospodarczej, Wydawnictwo Poznańskie, Poznań.

18. Florczak E. (2009), Przedsiębiorstwo spoteczne, Kwartalnik Nauk o Przedsiębiorstwie, Nr 4 (13), s. 35-41.

19. Florczak E., Gardziński T. (2019), Social enterprise in the order of social market economy, "International Journal of New Economics and Social Sciences”, Międzynarodowy Instytut Innowacji NaukaEdukacja-Rozwój w Warszawie, Warszawa, s. 127-145.

20. Gardziński T., Łabenda A. (2020), Spótdzielnia socjalna jako dynamicznie powstające przedsiębiorstwo spoteczne, Myśl Ekonomiczna i Polityczna, Nr 2 (69), s. 11-33.

21. Gardziński T. (2020), Metodologia teorii tadu spoteczno-gospodarczego w zarządzaniu przedsiębiorstwem spotecznym, w: Prospoteczność w życiu spoteczno-gospodarczym w XXI wieku, M. Dahl, E. Florczak (red.), Oficyna Wydawnicza Uczelni Łazarskiego, Warszawa, s. 97-153. 
22. Gospodarka społeczna w Unii Europejskiej (2006), Streszczenie sprawozdania sporządzonego dla Europejskiego Komitetu Ekonomiczno-Społecznego przez CIRIEC (Międzynarodowe Centrum Badań i Informacji na temat Gospodarki Publicznej, Społecznej, Spółdzielczej).

23. Grabska A., Moszyński M., Pysz P. (2014), Stanowiony i spontaniczny lad gospodarczy w procesie transformacji systemowej Polski i bytej NRD, Instytut Badań Gospodarczych, Polskie Towarzystwo Ekonomiczne, Oddział w Toruniu.

24. GUS, https://stat.gov.pl/wskazniki-makroekonomiczne/ (dostęp 07.04.2021).

25. GUS, Organizacje non-profit w czasie epidemii COVID-19 (marzec - sierpień 2020), https://stat.gov.pl/ obszary-tematyczne/gospodarka-spoleczna-wolontariat/gospodarka-spoleczna-trzeci-sektor/organizacjenon-profit-w-czasie-epidemii-covid-19-marzec-sierpien-2020,20,1.html (dostęp 12.04.2021).

26. Kołodko G.W. (2013), Dokąd zmierza świat. Ekonomia polityczna przysztości, Prószyński i S-ka, Warszawa.

27. Kołodko G.W. (2020), Pandemia: praktyczne reakcje i teoretyczne pytania, „Kwartalnik Nauk o Przedsiębiorstwie" 55 (2), s. 5-14.

28. Konstytucja Rzeczpospolitej Polskiej z 2 kwietnia 1997 r. (DzU nr 78, poz. 483).

29. Leś E. (2008), Gospodarka spoteczna i przedsiębiorstwo spoteczne. Wprowadzenie do problematyki, WUW, Warszawa.

30. Leś E., Ołdak M. (2007), Przedsiębiorstwo spoteczne w rozwoju lokalnym, Collegium Civitas Press, Warszawa.

31. Malinowski G.M. (2020), Zasada ostrożności, czyli teoretycznie ustrukturyzowana panika w czasach COVID-19, „Kwartalnik Nauk o Przedsiębiorstwie” 56 (3), 5-26.

32. Mączyńska E., Pysz P (2003), Spoteczna Gospodarka Rynkowa, Idee i możliwości praktycznego wykorzystania $w$ Polsce, PTE, Warszawa.

33. Mączyńska E., Pysz P. (2010), Idee ordo i spoteczna gospodarka rynkowa, PTE, Warszawa.

34. Moszyński M. (2016), Niemiecki model Spotecznej Gospodarki Rynkowej-perspektywa rynku pracy, Wydawnictwo Naukowe UMK, Toruń.

35. Moszyński M., Wiśniewski Z. (2020), Polityka rynku pracy w spotecznej gospodarce rynkowej Niemiec, Wydawnictwo Naukowe UMK, Toruń.

36. Pysz P., Jurczuk A. (2021), Spoteczna gospodarka rynkowa, geneza, źródta, zasady, w: Prospoteczność w życiu spoteczno-gospodarczym w XXI wieku, Dahl M., Florczak E (red.), Oficyna Wydawnicza Uczelni Łazarskiego, Warszawa, s. 15-39.

37. Pysz P. (2008), Społeczna gospodarka rynkowa. Ordoliberalna koncepcja polityki gospodarczej, Wydawnictwo Naukowe PWN, Warszawa.

38. Rozporządzenie Parlamentu Europejskiego i Rady (UE) nr 1296/2013 z dnia 11 grudnia 2013 r. w sprawie programu Unii Europejskiej na rzecz zatrudnienia i innowacji społecznych („EaSI”), s. 241.

39. Wünche H.F. (2000), Czego chciat wtaściwie Erhard?, w: Haberman G. (red.), Wizja i czyn-brewiarz Ludwiga Erharda, Wydawnictwo Ott, Thun.

Mgr Tomasz Gardziński, Uczelnia Łazarskiego, doktorant SGH Warszawa, tomasz.gardzinski@lazarski.pl 